\title{
"We the people:" On Popular Participation and the Making of the 2010 Constitution of Kenya
}

\author{
Dr. John Mukuna \\ Senior Lecturer, Botswana Accountancy College \\ Email: johnm@bac.ac.bw \\ Professor Melvin LM Mbao \\ Executive Dean and Professor of Public Law and Legal Philosophy, \\ North West University, South Africa \\ Email:Melvin.Mbao@nwu.ac.za
}

\section{Doi:10.5901/mjss.2014.v5n20p85}

\section{Abstract}

Kenya's 2010 constitutional project was predicated on the need to tackle almost fifty years of presidential authoritarianism entrenched through fundamental amendments to the 1963 independence Constitution. Attempts to whittle down presidential power were met with brutal force orchestrated by successive administrations of the ruling party, KANU. The 2002 opposition victory did not yield a constitution as the coalition partners took opposing views on key aspects of the draft constitution. Without a constitution, the country went into the 2007 election. Widespread violence and deaths ensued after that election which triggered the process of the making of the 2010 Constitution. The philosophical underpinning of the constitution-making process was that the people of Kenya would fully participate in the formation of their constitution. This article examines the legislative architecture of the constitution-making process with a view to exploring the magnitude of the participation of the people. In this vein, the article investigates the legitimacy of Kenya's constitution-making enterprise. This article finds that the 2010 constitution-making process was fundamentally flawed, which, consequently, renders the 2010 Constitution of Kenya illegitimate.

Keywords: Constitution; constitution-making; legislature; participation; legitimacy; authoritarianism

\section{Introduction}

August 272010 marked the promulgation of the new Constitution of Kenya. The 1963 Constitution had gone through numerous amendments. Those amendments essentially mutilated the basic architecture of the Constitution by embracing the political will of the country's first President, Jomo Kenyatta and his successor Daniel arap Moi. ${ }^{1}$ Moi succeeded Kenyatta in 1978 in a peaceful transition of power after the death of Kenyatta. The road to the new Constitution was long and tortious indeed.2

The term "reforms" was not in vogue in the 1980s when the struggle for political change in Kenya garnered momentum. Nevertheless, it is argued that the battle for constitutional amendments or what later became known as "reforms" commenced after the 1964 constitutional amendment which transformed the country from a parliamentary to a presidential system of government under Jomo Kenyatta. According to Okoth-Ogendo, at independence, the main

\footnotetext{
"This article is a version of a LLD thesis by John Mukuna, Political Governance and Constitution-making in Kenya: In Search of Popular Participation (unpublished) November 2012: North-West University, Mafikeng Campus South Africa.

1 For an exhaustive examination of the 1963 Constitution amendments, see generally, Muigai, "Amending the Constitution: Lessons from History," Report of the Constitution of Kenya Review Commission Vo. 5 (2003) pp304-320; K Kindiki, "The Emerging Jurisprudence on Kenya's Constitutional Review Law," 1:153 (2007) Kenya Law Review pp153-187. Also see Y Ghai and J McAuslan, Public Law and Political Change in Kenya: A Study of the Legal Framework of Government from the Colonial Times to the Present Day, London: Oxford University Press 1970.

2 Some of the leading works on Kenya's struggle for democratization include L Mute and SWanjala (eds.), When the Constitution Begins to Flower: Paradigms for Constitutional Change in Kenya (2002); W Mutunga, Constitution-Making from the Middle: Civil Society and Transition Politics in Kenya (1999) and G Murunga and R Nasong'o, (eds) The Struggle for Democracy in Kenya, (2007).
} 
intention of Kenyatta's political vehicle, the Kenya African National Union (KANU) was that the colonial administration would merely transfer power to Africans. ${ }^{3}$ This then must have been the motive behind a relentless effort of amending constitutional provisions which were a barrier to centralisation and personification of power. Factors underpinning the struggle for constitutional amendments under the two regimes included blatant violations of human rights and the rule of law, unbridled impunity, corruption, ethnicisation of politics and the "strong man" syndrome as the presidency personified power.

There was un-relented clamour for reforms heightened by the end of the Cold War in the late 1980s. ${ }^{4}$ Some of the constitutional provisions which entrenched presidential authoritarianism were repealed by Parliament. Specifically, multiparty democracy was restored in 1992 and the President's direct grip on the judiciary was loosened as the removal of judges of the High Court and of the Court of Appeal was taken away from the presidency and back to the Judicial Service Commission which, unfortunately, was indirectly under the control of the President. ${ }^{5}$

Under the challenging political environment then prevailing, these reforms marked a major stride in the struggle for the country's democratization. Most importantly, they demystified the entire political reforms initiative and indeed set the tone for future constitutional reforms. It is no surprise then that the preamble to the 2010 Constitution honours those who heroically struggled to bring freedom and justice to Kenya.

The aim of this article is to examine the process of the 2010 constitution-making and the legitimacy of that Constitution. The foundation of this inquiry is an examination of the statute underpinning the constitution-making process, the Kenya Review Act 9 of 2008 (hereinafter "the Review Act"). Secondly, the myriad governance ills prevailing under the old Constitution meant that a new paradigm in constitution-making anchored on the participation of the people was imperative so as to clothe the entire process of constitution-making and the final product with legitimacy. The question is whether the 2010 constitution-making process effectively and meaningfully translated into the recognition that sovereign power lay directly with the people of Kenya.

\section{The People and the 2010 Constitution-Making}

The key statutory foundation of the constitution review exercise was the Review Act. The Act adopted the philosophy that sovereign power vests with the people and that those exercising it do so as the peoples' delegates. ${ }^{6}$ An examination of the new Constitution and the statutory structure underpinning its formation suggest an unequivocal intent and spirit of its drafters to depart from the indirect or representative democratic posture in the old Constitution to a hybrid system of direct and indirect democracy. To begin with, the preamble of the new Constitution in "We the people" declaration, states that the people of Kenya participated fully in the making of the Constitution.

Unlike the old Constitution which was silent on the notion of sovereign power, the 2010 Constitution provides that sovereign power belongs to the people of Kenya and it may be exercised directly or through the State organs at the national and county level. ${ }^{7}$ The State organs to whom the sovereign power of the people is delegated are Parliament, the executive and the judiciary and independent tribunals. ${ }^{8}$ It is on the basis of the sovereignty of the people of Kenya that we explore the extent of their participation in the making of the 2010 Constitution.

The preamble of the Review Act stated the Act's aim as "to facilitate the completion of the review of the Constitution of Kenya, and for connected purposes." In this regard, the Review Act provided that the constitutional review process provided "the people of Kenya with an opportunity to actively, freely and meaningfully participate in the generating, and debating proposals to the review to replace the Constitution." ${ }^{\prime \prime}$ Against the background of contemporary principle that the people, as discussed above, have to own the process of constitution-making, it is necessary to answer the question whether Kenya's constitution-making process had legitimately commenced so that Parliament could legislate for the "completion" of the review process as stipulated in the Review Act.

${ }^{3}$ H Okoth-Ogendo, "The Politics of Constitutional Change in Kenya since Independence, 1963-1969," 71:282 (1972) African Affairs 9. Also see generally, JB Ojwang, Constitutional Development in Kenya: Institutional Adaptation and Social Change (1990).

4 See for instance G Sabar-Friedman "Church and State in Kenya, 1986-1992: The Church's Involvement in the "Game of Change," (1997) African Affairs 25; D Throup \& C Harnsby, Multi-Party Politics in Kenya: The Kenyatta and Moi States and the Triumph of the System in the 1992 Election (1998); Wanyande et al Governance and Transition Politics in Kenya (2007).

${ }^{5}$ Constitution of Kenya (Amendment Act) No. 2 of 1990.Plural democracy was restored by the Constitution of Kenya (Amendment) Act No 12 of 1991 which repealed section $2 A$ of the Constitution which had made Kenya a de jure one-party (KANU) State.

${ }^{6}$ See for instance $s 6(b)$ and (d) (ii).

${ }^{7}$ Article 1()1-(4).

${ }^{8}$ Article 1 (3) of the 2010 Constitution of the Republic of Kenya.

${ }^{9}$ Section 6(d)(i). 
To determine the extent of participation of the people of Kenya in the making of the new Constitution, a conceptual analysis of the constitution-making process should be established. The importance of this endeavour is to underscore the notion of the constitution of a country as its supreme law. The making of the supreme law is perhaps the most important process in a country's legal and political history. This is because, to the citizens, a constitution "has a symbolic value." ${ }^{0} \mathrm{It}$ can be the foundation of security and identity of citizens although their views may differ. ${ }^{11}$ Those who are politically "in" on the basis of majoritarian and power perspectives are subjected to the criticisms of those who are politically "out" "while simultaneously communicating to all their common national membership." 12 A modern constitution is not so much seen as a political "power map", as Okoth-Ogendo would have called it, rather it is the take-off point towards constitutionalism and the rule of law. ${ }^{13}$

To achieve the legitimacy of a modern constitution, Ghai has argued that the process of constitution-making should be an inclusive one in a manner which "strengthens national unity and a sense of common, national identity."14 The place of a constitution in a contemporary political system is not only found in legal and political discourses. The UN has provided assistance to countries emerging from political turbulence to establish constitutions as they are central to democratic transitions. ${ }^{15}$ In this regard, the UN puts emphasis on a credible constitution, both in process and substance, because of its role in resumption of peace and in averting similar strife as in the past. ${ }^{16}$ Even when a nation is emerging from a political crisis, for instance Kenya's 2007 post-election violence, Tribe and Landry argue that:

The temptation to hammer out a constitutional accord as quickly as possible - to seize the historical moment, must be balanced against sombre reality that speed is not the only desideratum if the constitution is to be than simply one stop among many in a series of radical transformation. ${ }^{17}$

As argued below, it appears as if Kenya's new constitution-making exercise fell prey to the temptation of hammering out an accord as quickly as possible.

In constitution-making, the outcome or the end product is not necessarily what counts in determining the acceptability of the new law. Undoubtedly, substance is crucial, because the constitutional enterprise should address the issues of concentration of power and tyranny by entrenching the principles of liberty, equality and democracy. ${ }^{18}$ However, process and substance are both cardinal ingredients of the constitution-making enterprise. It is also risky to ignore that the whole project of constitution-making can, at the process stage, be manipulated and therefore systems should be put in place to mitigate this. ${ }^{19}$

On process, the UNDP is categorical that "constitution-making has to be a wide societal process in the full sense of the word." 20 In South Africa, for example, the painstaking constitution-making process which ushered in the 1996 Constitution had the National Assembly and the Senate as its Constitutional Assembly. ${ }^{21}$ The two bodies were democratically elected peoples' representatives and had to approve the Constitution by a two-thirds majority. ${ }^{22}$ In the process, the Constitutional Assembly endeavoured to engage the people in constitution-making and to avoid the charge that had been levelled at the interim Constitution-that it was an "elite pact". ${ }^{23}$

If the right design including an inclusive process to make the supreme law is adopted, it facilitates the fostering of

${ }^{10} \mathrm{LH}$ Tribe and TK Landry, "Reflections on Constitution-making," 8 (1993) American Journal of International Law and Policy, 627-646 p630.

11 Tribe and Landry, ibid at p631.

12 Tribe and Landry, ibid.

${ }^{13}$ JO Ihonvbere, "Towards a New Constitutionalism in Africa," Occasional Paper Series No. 4, Centre for Democracy and Development (CDD), London, April 2000. Available at http://www.kituochakatiba.org/index2.php?option=com.pp5-7.

${ }^{14} Y$ Ghai, "The Role of Constituent Assemblies in Constitution Making," International Institute for Democracy and Assistance (IDEA) (undated) p3. Available at www.constitutionnet.org.../the_role_of-constituent_assemblies_-_final .

${ }^{15}$ See generally, United Nations, "Guidance Note of the Secretary-General: United Nations Assistance to Constitution-making Processes," New York, April 2009. Available at www.agoa-parl.org/node/3484.

16 UN, ibid at $p 3$.

17 Tribe and Landry, ibid note 9 p628.

18 Tribe and Landry, ibid at p639.

19 Tribe and Landry, ibid at pp632 and 637.

20 UNDP: Centre for Constitutional Dialogue: Support to Participatory Constitution Making in Nepal p1. Available at www.ccd.org.np/new/publications/Participatory-Constitution-English.pdf.

${ }_{21}$ I Currie and J de Waal, The Bill of Rights Handbook 5th ed. Cape Town: Shunami Printers 2005 p6.

22 Currie and de Waal, ibid p6 foot note 21.

${ }^{23}$ Currie and de Waal, ibid. 
legitimacy, better enforcement and engenders fidelity to the constitution. The constitution is "not only a "basic law," or a higher law but our law." 24 Certainly, the desirability for a thorough public engagement in constitution-making is predicated on the constitution being a supreme law which is an embodiment of the sovereignty of the people and determines their country's system of governance. ${ }^{25}$ For these reasons, Colon-Rios argues that the constituent assembly should be elected in a way that promotes the participation of all the stakeholders; popular participation should occur in all stages of the process and it should take place in a context of strong popular support for constitutional change. ${ }^{26}$

It is therefore argued that meaningful participation of the people in the constitution-making process is the litmus test in measuring the legitimacy of the supreme law and the starting point towards the entrenchment of constitutionalism in a young democracy like Kenya. Further, examining the magnitude of the participation of the people in the constitutionmaking process would be gauging the extent of compliance with international law. For example, Article 13 (1) of the African Charter on Human and Peoples' Rights provides that "every person has the right to participate freely in the government of his country either directly or through freely chosen representatives..."

The desirability for the constitution-making process to be all inclusive is greater in countries that have emerged from active conflicts than those which reform their constitutions in times of peace. ${ }^{27}$ Without doubt, an all-inclusive process would boost reconciliation efforts in addition to the greater question of legitimacy of the new constitutional compact. In Kenya, the actual event which triggered an accelerated constitution-making process was the 2007 postelection crises. It is appropriate therefore to regard the new Constitution as a post-conflict supreme law.

In circumstances such as those prevailing in Kenya, Banks has argued that participation of the people in the drafting and implementation of the Constitution is imperative. The reason is that participation of the people forms a normative foundation of the constitution and gives it "a legitimate governance system." ${ }^{28}$ Kenya's 2010 Constitution emanates from the turbulence which arose after the 2007 general elections, and was indeed the central agenda in the Kenya National Dialogue and Reconciliation Committee initiative led by Kofi Annan ${ }^{29}$ As the Constitution is a product of the crisis. It therefore becomes necessary to interrogate the involvement of the people of Kenya from a constitutionmaking perspective and, consequently, the legitimacy of the 2010 Constitution.

\section{In Pursuit of the Legitimacy of the Constitution-Making Process}

A determination of the legitimacy of the 2010 constitution-making process is inseparable from the provisions of the Review Act. This is because the Review Act was the bedrock of the entire constitution-making process. Section 23 of the Review Act provided for the functions of the Committee of Experts $(\mathrm{CoE})$. The $\mathrm{CoE}$ was one of the organs of the review process. $^{30}$

The question of the legitimacy of the 2010 constitution-making process and consequently the Constitution can be traced in sections 23 and 29 of the Review Act. Section 23 (a) and (b) provided that the CoE would identify the issues already agreed upon in the existing drafting constitutions and the issues which are contentious or not agreed upon in the existing draft constitutions.

Section 29 identified the draft constitutions mentioned in section 23. According to section 29(b), the draft constitutions were "the various draft constitutions prepared by the Commission and the Constitutional Conference." Apart from these draft constitutions, section 29(c) provided for another draft constitution, the Proposed New Constitution of Kenya, 2005. In addition to these primary sources, the work of the CoE was to consider other materials such as what section 29 (d) called, "the Naivasha Accord." These were the bits and pieces which the CoE was expected to collect and reconcile by collating the views of Kenyans on 'contentious issues.' In addition there was what the Review Act referred to

24 T Regassa," The Making and Legitimacy of the Ethiopian Constitution: Toward Bridging the Gap between Constitutional Design and Constitutional Practice," 23:1 (2010) Africa Focus 85-118 p88.

${ }^{25}$ See generally, M Mbao, "The Politics of Constitution-making in Zambia: Where Does the Constituent Power Lie? In C Fombad and C Murray (eds.) Fostering Constitutionalism in Africa (2010) pp 87-117.

${ }^{26}$ See, J Colon-Rios. "Notes on Democracy and Constitution-Making," 9:1 (2011) New Zealand Journal of Public International Law pp 117. Available at $h$ ttp://papers.ssrn.com/sol13/papers.

27 See generally Ghai ibid note 14.

${ }^{28}$ AM Banks, "Expanding Participation in Constitution-making: Challenges and Opportunities," 49:4 (2008) William and Mary Law Review 1043-1069 p1046.

${ }^{29}$ Agenda Item 4 of the Kenya National Dialogue and Reconciliation Committee focused on constitutional reforms as key to reconciliation efforts.

30 Section 5(a) of the Review Act. 
as "analytical and academic studies commissioned or undertaken by the Commission or the Constitutional Conference." 31 Such sources of the supreme law may perhaps be close to what Mayer calls "a bag of marbles."32

It is worth noting that these materials were not the only sources of constitution-making which the $\mathrm{CoE}$ had to consider. Section 29 vested the $\mathrm{CoE}$ with jurisdiction of sourcing for information by providing that the materials included "but not limited to..." After identifying issues which were contentious, section 30 (2) of the Review Act required the CoE to invite representations from the public, interest groups and experts on contentious issues so as to resolve them and merge these with the issues already closed and agreed upon so as to create a harmonized draft Constitution.

Thereafter, the draft constitution had to go through the Parliamentary Select Committee (PSC) for consensus building on the contentious issues as determined by the CoE, then back to the PSC and finally the National Assembly as detailed in section 32 of the Review Act. The remainder of this article examines two elements of the 2010 constitutionmaking process which we consider germane in the pursuit of the legitimacy of the Constitution. These are: (i) Popular participation and the draft Constitutions and (ii) Whether the CoE was the constituent assembly.

\subsection{Legitimacy, Popular Participation and the Draft Constitutions}

The legitimacy of a constitution should not be assumed because "legitimacy comes between the "justice of laws and their validity." ${ }^{33}$ As Fallon has argued, an enquiry of the legitimacy of a constitution is based on the perspectives of legal legitimacy, moral legitimacy and sociological legitimacy. ${ }^{34}$ Legal legitimacy is about the legal norms surrounding a constitution. 35

The legislative genesis of the constitutional review process was the Constitution of Kenya Review Commission Act of 1997. This Act was the product of the Moi regime giving in to sustained local and international pressure for constitutional and legal reforms ${ }^{36}$ The Act was a product of negotiated settlement between the politically appointed InterParty Parliamentary Group (IPPG) composed of members of various political parties represented in the National Assembly. The IPPG initiative was intended by Parliament to be the vehicle through which a comprehensive review of the Constitution would be undertaken. ${ }^{37}$

The IPPG was viewed by reform advocates as an affront to the people of Kenya. This was because the IPPG initiative was exclusively comprised of legislators. To the National Council of Churches of Kenya (NCCK) and the Catholic Church, the IPPG reforms did nothing to mitigate Moi's hold on power. Kamau Kuria, one of the foremost crusaders for reforms, argued that the IPPG process had usurped the people's right to participate in the making of their Constitution. ${ }^{38}$ By 1997 when Moi dissolved the National Assembly after its five year-term, no meaningful reforms had been commenced.

The struggle for reforms continued in earnest after Moi's 1997 re-election as President. However, there were two parallel groups, the statutory Constitution of Kenya Review Commissioners appointed under the 1997 Act and what was known as the Ufungamano Initiative. The Ufungamano Initiative was composed of key religious and civil society organizations which created a formidable constitutional review team, the Peoples' Commission of Kenya.

Yash Ghai, the chairperson of the Constitution of Kenya Review Commission negotiated a merger between the two groups after the amendment of the Constitution of Kenya Review Act by the Constitution of Kenya Review (Amendment) Act 2001. The commissioners collated diverse views on a new Constitution and a draft Constitution was unveiled in 2002. ${ }^{39}$ However, its time lapsed and by the time the opposition coalition, the National Rainbow Coalition (NARC) under

\footnotetext{
${ }^{31}$ Section 29(e) of the Constitution of Kenya Review Act 9 of 2008.

${ }^{32}$ The term is in reference to the many sources of international law on environmental migration, see B Mayer, "Sustainable Development Law on Environmental Migration: The Story of an Obelisk, a Bag of Marbles, and a Tapestry," Environmental Law Review 14:2(2012) 111-132.

${ }^{33}$ RE Barnett, "Constitutional Legitimacy," 103 (2003) Columbia Law Review 111-148 p111.

${ }^{34}$ RH Fallon, Jr. "Legitimacy and the Constitution," 118:6 (2003) Harvard Law Review pp1787-1853 p1787.

${ }^{35}$ Fallon, ibid p1794.

${ }^{36}$ Key forces for reforms included The Catholic and Anglican Churches; Rev. Timothy Njoya; Bishops Henry Okullu and Kipsang Muge; lawyer Kamau Kuria; the Law Society of Kenya; former University of Nairobi lecturers including the current Chief Justice Willy

Mutunga; some sections of the media; politicians Oginga Odinga, Raila Odinga, Kenneth Matiba and Stanley Rubia, see generally, S Ndegwa, "Civil Society and Political Change in Africa: The Case of Non-governmental Organizations in Kenya," 35:1994 International Journal of Comparative Sociology pp. 19-36 and Murunga and Nasong'o ibid note 2.

${ }^{37}$ Law Society of Kenya Final Report of the Standing Committee on Constitutional Review, August 2006 p11.

${ }^{38} \mathrm{~A}$ Oloo and W Oyugi, "Democracy and Good Governance in Kenya: Prospects and Obstacles," Development Policy Management Forum (DPMF) Publications 1991 p11.

${ }^{39}$ Kindiki op.ibid note 1 p154.
} 
Mwai Kibaki won the 2002 elections, the country was still under the yoke of the mutilated independence Constitution. There is no doubt then that the 2002 CKRC Constitution referred to in section 29 of the Review Act lacked legitimacy. Its composition was a hybrid of peoples' elected representatives, who were a minority, while the majority were not the peoples' representatives.

As observed by Cottrell and Ghai, after the 2002 opposition victory, there was a general consensus among all parties that the constitution-making process had to begin in earnest and should be democratic, fully participatory and transparent. ${ }^{40}$ However, no major shift in the constitution-making process was adopted in 2003. In particular, most of the delegates were not elected by the people.

In creating the Bomas Draft Constitution, the NCC under Yash Ghai functioned under the 1997 CKRA. The legitimacy of this Act as the cardinal instrument underpinning the constitution-making process was at the heart of what became a landmark decision in the jurisprudence of constitution-making in Kenya, the case of Njoya and 6 Others $v$ Attorney General and 3 Others (No 2). ${ }^{41}$ The applicants had approached the Court claiming that certain provisions of the CKRA 1997 had vitiated their constituent power or were unconstitutional and should be struck out.

The applicants sought the suspension of the constitution-making process until measures were put in place for compliance with the Constitution. ${ }^{42}$ According to Ringera Ag J, the 1997 Act was the government's response to persistent and sometimes violent pressure by the people of Kenya for constitutional reforms. The Act had to be amended several times so as to make the review process "all inclusive and people-driven." 43

Two key issues in the case of Njoya are relevant to our discussion. One was the interpretation of section 47 of the old Constitution to determine whether the word "alter" the Constitution also embraced the abrogation and the enactment by Parliament of a new one in its place. Secondly and equally important was the question of the legitimacy of the NCC, a key organ mentioned in section 27 (1) of the Review Act. In interpreting the Constitution, the Court observed that constitutional interpretation is a different exercise from interpretation of an Act of Parliament. The Constitution had to be construed liberally and purposely. ${ }^{4}$

The composition of the NCC was at the heart of the validity or otherwise of the proceedings and the product of Bomas. To determine this question, the High Court in Njoya held that the number of Members of Parliament, the peoples' representatives, was outweighed by other stakeholders or delegates who were representing other interests. The Court observed that the entire membership consisted of 629 delegates. Out of those "only 210 elected members of Parliament could claim to have been directly elected by the people...Thus on the whole, only one-third of the membership of the National Constitutional Conference was directly elected by the people". ${ }^{45}$

The Court further noted that the mark of the sovereignty of a people was their constituent power, the power to constitute their framework of government. It added that constituent power of the people was primordial and for this reason, a constitution need not contain an express provision of the exercise of this power by the people. ${ }^{46}$ The court also held that Parliament had no power to replace the Constitution, its power being limited only to alterations of the Constitution. The power to make a new Constitution, the constituent power, vested in the people of Kenya as a whole. ${ }^{47}$

After the Njoya judgment, Parliament enacted the Constitution of Kenya (Amendment) Act 2004 which the High Court in Oyango and 12 Others v Attorney General and 2 Others ${ }^{48}$ called the "Consensus Act." 49 The case of Onyango was about the validity of the process leading to the "Consensus Act." For purposes of this article, what was pertinent in Onyango was on the issue of the invalidity of the Bomas process as held in Njoya. The Court made the succinct observations that "The big mistake was the unforgivable failure by those offering legal services to the Government in 1997 and thereafter including the CKRC not to have thought of, or contemplated the role of the people in constitutionmaking". ${ }^{50}$ The Court in Onyango further upheld the observations in Njoya on the tumultuous environment of the Bomas process which significantly dented its credibility. ${ }^{51}$

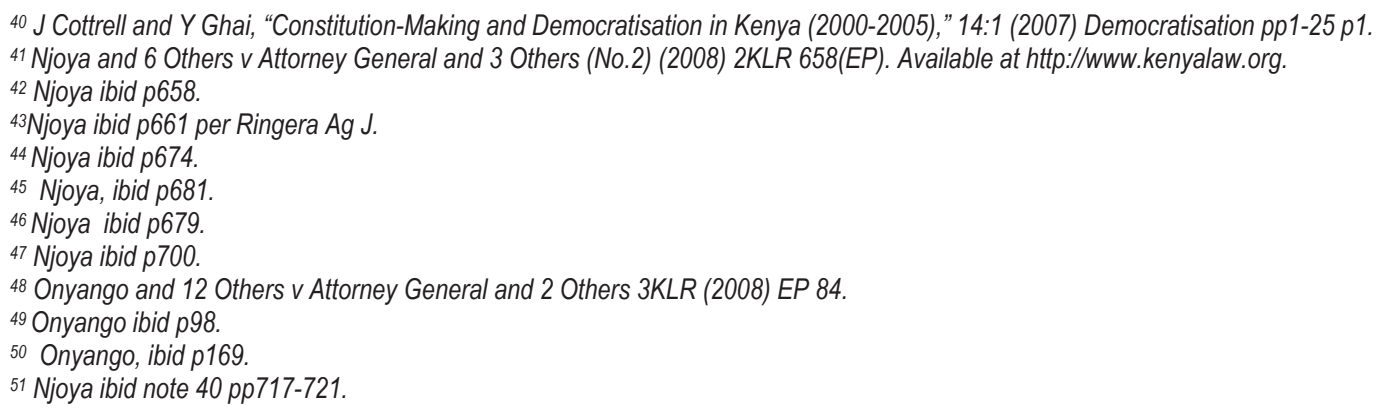


In 2005, Members of Parliament associated with Kibaki's wing of the coalition met in Kilifi in the Coast Province to find solutions to the contentious matters in the 2004 Bomas Draft Constitution. KANU and Raila Odinga's LDP faulted this process and refused to attend. Instead, they insisted on the tabling of the Bomas Draft in Parliament. Steered by the then Attorney-General, Amos Wako, the Kilifi meeting crafted a Draft Constitution, the Proposed Constitution of Kenya 2005. This is the draft constitution referred to by section 2 of the Review Act as "The Wako Draft" clearly because of the role played by the Attorney-General, Amos Wako, in making of the Draft Constitution.

The Wako Draft was resoundingly defeated in the 2005 referendum by the Raila Odinga-led pro-Bomas Draft advocates. While the Bomas Draft embraced a drastic shift from presidential hegemony, the Wako Draft Constitution had all the hallmarks of presidential authoritarianism..$^{52}$ On the basis of the cardinal principle of participation of the people in constitution-making either directly or through their chosen representatives, the Bomas and the Wako Draft Constitutions were fundamentally flawed and consequently failed to meet the legitimacy test. The Wako Draft Constitution was even more illegitimate as the changes to the Bomas Draft were made by one arm of the NARC coalition.

The exclusion of people of Kenya in the 2010 constitution-making was exacerbated by the powers granted to the Committee of Experts by the Review Act. Whereas section 4 of the Review Act provided for a meaningful participation of the people in the constitution-making process and for the process to faithfully reflect the wishes of the people of Kenya, section 23 of that Act vilified that right. It is therefore apposite to examine the functions of the CoE under the Review Act. In particular, the CoE's mandate was to identify the issues already agreed upon in the existing draft constitutions; identify the issues which are contentious or not agreed upon in the existing draft constitutions; receive from the public written memorandum and presentations on the contentious issues; make recommendations to the Parliamentary Select Committee on the resolution of the contentious issues in the context of the greater good of the people of Kenya and to prepare a harmonised draft constitution for presentation to the National Assembly.

It is clear therefore, that the $\mathrm{CoE}$ could only collate views from the people on contentious issues in the draft constitutions. That approach does not embrace the philosophy of a robust constitution-making process anchored in section 4 of the same Act. Eight years had passed since the first Draft Constitution in 2000 and even those matters which were not contentious required re-examination. The preamble to the 2010 Constitution provides that:

\begin{abstract}
We, the people of Kenya...exercising our sovereign and inalienable right to determine the form of governance of our country and having participated fully in the making of this Constitution, adopt enact and give this Constitution to ourselves and to our future generation.
\end{abstract}

The people of Kenya did not in any meaningful way participate in the making of the 2010 Constitution as claimed in the preamble to the Constitution. The process was a clear violation of jurisprudence and doctrines embedded in scholarly discourses on constitution-making. As Arato would probably observe, the 2010 Kenya's constitution-making process lacked significant traits of a democratic and sovereign constitution-making. ${ }^{53}$

\title{
3.2 Was the CoE the Constituent Assembly?
}

A Constituent Assembly is the supreme constitution-making body. In modern constitution-making, the Constituent Assembly must be elected by the people who are the owners of the supreme law. Thus, members of a nation's lawmaking body or bodies may convert themselves into a constituent Assembly. Alternatively, the people may elect members of the assembly with the sole aim of constitution-making. ${ }^{54}$ In the case of Njoya, the Court observed that notwithstanding the absence of express constitutional or other provisions, Members of Parliament had the power to make a new Constitution because they were the peoples' representatives, and could therefore participate in the making of a new Constitution. ${ }^{55}$

Under the Review Act, the organs of the review of the Constitution were the CoE; the Parliamentary Service Commission; the National Assembly and the referendum. ${ }^{56}$ The $\mathrm{CoE}$ was composed of three non-citizens of Kenya nominated by the National Assembly from a list of names submitted to the Parliamentary Select Committee by the Kofi

\footnotetext{
52 For example, section 173 (1) of the Bomas Draft gave power to the President to appoint, as Prime Minister, a member of the National Assembly who was the leader of the largest political party or coalition of parties represented in the National Assembly.

${ }^{53}$ A Arato, "Forms of Constitution-making and Theories of Democracy," 17 (1995-96) Cardozo Law Review 191-231 p203. Available at http://www.heinonline.org.

${ }^{54}$ See generally, UN, ibid note 42; Colon-Rios, ibid note 25.

55 Njoya, ibid note 40 p681.

${ }^{56}$ Section 5 (a)-(d).
} 
Annan-led mediation team in consultation with the KNDRC. ${ }^{57}$ The other six members were citizens of Kenya nominated by the National Assembly. ${ }^{58}$ The Attorney-General and the Director of the CoE were ex-officio members of CoE but had no voting rights. ${ }^{59}$ It is necessary to explore the legitimacy of the constitution-making process by examining which organ among the PSC; the National Assembly and the CoE was the Constituent Assembly.

The CoE was nominated by Parliament which significantly ousted or surrendered its constitution-making power to the $\mathrm{CoE}$. The Review Act provided the CoE's main function as the preparation of a draft Constitution. ${ }^{60}$ After preparing the draft Constitution, the CoE had to present the draft Constitution to the Parliamentary Select Commission (PSC) for discussion, agreement "and consensus building on the contentious issues on the basis of the recommendations of the Committee of Experts." ${ }^{61}$ It is therefore apparent that the PSC had no control whatsoever in the determination of contentious issues, the bedrock of the 2010 Constitution-making process. That was the sole mandate of the $\mathrm{CoE}$.

It is contended that the PSC had no jurisdiction to overturn the findings of the COE on contentious matters. In any case, it was the CoE which collated the views of the people on contentious matters. After "taking into account the achieved consensus" 62 of the PSC, the CoE revised the draft Constitution and submitted it together with its final report to the PSC which tabled them before the National Assembly as provided for in the Act. ${ }^{63}$ Thereafter, the National Assembly had to either approve or "propose amendments" to the draft Constitution to the CoE for consultation and re-drafting. ${ }^{64}$ It is clear that the National Assembly could only "propose" amendments of the draft Constitution which the CoE could "consider." 65

To demonstrate that the CoE was neither bound by the proposals of the PSC nor by those of the National Assembly, the Chairperson of the $\mathrm{CoE}$ observed in the final report of the $\mathrm{CoE}$ on constitutional review that:

In sum, we respected most of the decisions of the politicians related to the mandate of the Parliamentary Select Committee of assisting us in the resolution of contentious issues. The Parliamentary Select Committee most generously strayed into the arena of none-contentious issues and made suggestions some of which we also considered and incorporated into the Proposed Constitution of Kenya. 66

Unarguably, therefore, the function of the PSC was to only assist the COE in the determination of contentious issues. Quite surprisingly, the PSC also assisted the $\mathrm{CoE}$ in the incorporation into the draft Constitution of nonecontentious issues. This was undoubtedly ultra vires the powers granted to the $\mathrm{CoE}$ by the Review Act. This is clear from the COE Chairperson's remarks that the PSC "generously strayed" into none-contentious issues some of which the CoE readily took on-board. We therefore contend that the constitution-making process was fundamentally in the hands of the $\mathrm{CoE}$, a non-elected body and which, on some issues, exceeded its jurisdiction. This further inflicted a significant dent to the legitimacy of the 2010 Constitution.

\section{Conclusion}

This article has examined the making of the 2010 Constitution of Kenya from the perspective of the notion of popular participation underpinned by the Constitution of Kenya Review Act 9 of 2008 (the Review Act). The Act established the road-map of the constitution-making process with the intention of tackling the country's despicable governance record the architecture of which was the myriad amendments to the 1963 Constitution. It was those amendments which entrenched the 'big-man' syndrome. The Review Act created the organs for constitutional review.

The organs for the constitutional review were the PSC, The National Assembly, the CoE and the referendum. On the basis of the requirement that a modern constitution-making process should be owned by the people, the constitutionmaking process failed to meet this cardinal threshold. This renders the 2010 Constitution illegitimate for two main

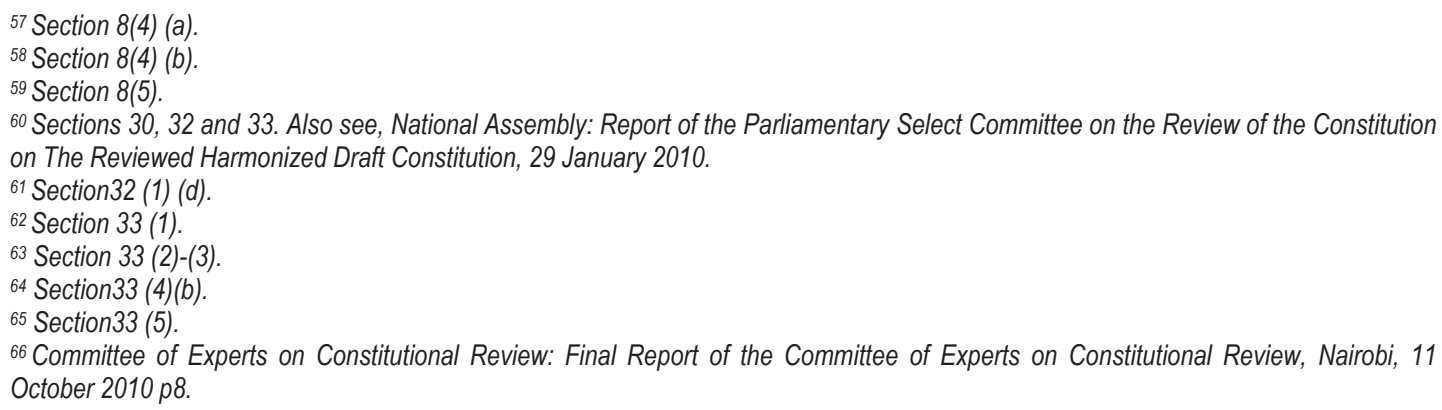


reasons. Firstly, apart from participating in the referendum, the people did not meaningfully participate in the constitutionmaking process. This is because the main task of the $\mathrm{CoE}$ was to examine the contentious issues in the draft constitutions and harmonise them. They were the 2002 NCC Draft Constitution, the 2004 Draft Constitution (Bomas Draft) and the 2005 Proposed Constitution of Kenya (Wako Draft).

The formation of these draft constitutions did not engage the people because most of the delegates who made the 2002 and the 2004 Draft Constitutions were not the peoples' representatives. The 2005 Draft Constitution took a further step towards illegitimacy because it was a product of one wing of the assembly which created the 2004 Draft Constitution. Secondly, it has been established that the CoE was the constituent assembly because neither the PSC nor the National Assembly had the statutory power to alter the findings of the CoE.

The main responsibility of the peoples' representatives was to assist the CoE in the harmonisation of the contentious issues in the draft constitutions. As the constituent assembly, the CoE was not elected by the people of Kenya which goes against settled jurisprudence of modern constitution-making. In addition, some matters considered by the $\mathrm{CoE}$ were not contentious which further exacerbates the illegitimacy of the 2010 Constitution of Kenya. For the country to have a people-driven and people-owned constitution, an appropriate framework should be put in place for the making of a constitution which meets best practice in contemporary constitution-making so that the people may own their supreme law. Because of the complex nature of this process under Kenya's political environment, the people of Kenya must in the meantime be fully engaged in key affairs of State and in all amendments to the Constitution. This approach would vest the Constitution with some legitimacy.

\section{References}

Arato, A "Forms of Constitution-making and Theories of Democracy, 17 (1995-96) Cardozo Law Review 191-231

Banks, A "Expanding Participation in Constitution-making: Challenges and Opportunities," (2008) William and Mary Law Review 10431069

Cottrell, J \& Ghai Y "Constitution-making and Democratization in Kenya 14:1(2000-2005)," (2007) 14:1 Democratization1-25

Currie, I \& de Waal, J The Bill of Rights Handbook $5^{\text {th }}$ ed. (2005) Fallon, R "Legitimacy and the Constitution," (2003) Harvard Law Review 118:1787-1853

Ghai, YP and McAuslan, JP Public Law and Political Change in Kenya: A Study of the Legal Framework of Government from the Colonial Times to the Present Day (1970)

Ghai, Y "The Role of Constituent Assemblies in Constitution Making," International Institute for Democracy and Electoral Assistance," (2011)

Ghai, Y "Decreeing and Establishing a Constitutional Order: Challenges Facing Kenya." The Royal African Society: African Arguments (2009)

Goredema, C "The Attorney General in Zimbabwe and South Africa: Whose Weapon? Whose Shield?" (1997) Stellenbosch Law Review 45-64

Kindiki, K "The Emerging Jurisprudence on Kenya's Constitutional Review Law", (2007) Kenya Law Review 153-187

Mbao, M "The Politics of Constitution-making in Zambia: Where Does the Constituent Power Lie? in Fombad C, and Murray C, (eds.) Fostering Constitutionalism in Africa (2010) 87-114

Murunga, G \& Nasong'o S "Bent on Self-Destruction: The Kibaki Regime in Kenya," (2006) Journal of Contemporary African Studies 128

Musila, G "The Office of the Attorney General in East Africa: Protecting Public Interest through Independent Prosecution and Quality Legal Advice" ( 2010) South African Institute for Advanced Constitutional, Public, Human Rights and International Law

Mutua, M "Justice under Siege: The Rule of Law and Judicial Subservience in Kenya," (2001) Human Rights Quarterly 96-118

Mutunga, W Constitution-Making from the Middle: Civil Society and Transition Politics in Kenya, 1992-1997 (1999)

Odhiambo-Mbai, C "The Rise and Fall of the Autocratic State in Kenya," in Oyugi, W., et al, The Politics of Transition in Kenya: From KANU to NARC $51-59$ (2003)

Ojwang, J B Constitutional Development in Kenya: Institutional Adaptation and Social Change (1990)

Okoth-Ogendo, H "Constitutions without Constitutionalism: Reflection of an African Political Paradox," in Shivji, I G (ed) State and Constitutionalism: An African Debate on Democracy 63-82 (1991)

Throup, D \& Harnsby, C Multi-Party Politics in Kenya: The Kenyatta and Moi States and the Triumph of the System in the 1992 Election (1998)

Wanyande et al Governance and Transition Politics in Kenya (2007)

Wanyande, P "The Media as Civil Society and its Role in Democratic Transition in Kenya," (1997) African Media Review 1-20

Whitaker, B \& Giersch, J "Voting on a Constitution: Implications for Democracy in Kenya," (2009) Journal of Contemporary African Studies 1-20. 